\title{
Avifauna of the Lake Systems in the Delta of the Syr Darya River (Lake Cartma)
}

\author{
N.S. Sihanova ${ }^{1}$, I.I. Rahimov ${ }^{1}$ \\ ${ }^{1}$ Kazan Federal University, Institute of Fundamental Medicine and Biology, Kremlevskaya Str., 18, Kazan, \\ Russia, 420008. \\ E-mail:muhtasar_08@mail.ru, contact: +7 (927) 4099233
}

\section{Received: 21st October 2017 Accepted: 16th November 2017, Published: 31st December 2017}

\begin{abstract}
The change in the indicator of specific variety and the quantitative structure of the population of birds in the system of lakes of the SyrDarya River delta (Lake Cartma)were analyzed by the authors. Since 2012, Syr Darya River lake system has been included in the Convention on the Wetlands of International Importance Especially as Wildlife Habitat, also called Ramsar Convention. Change in the level of the Syr Darya River directly affects water security of Lake Cartma. The object of the research is water objects, restored according to the program "Syr Darya Control and Northern Aral Sea" Project (SYNAS).Investigations were carried out for the purpose of studying the avifauna of Lake Cartma. Defining the status of residence of bird species in the restored zone of a coastal strip was a basic task. 59 bird species from 10 groups with total quantity of 3147 individuals were noted. According to the abundance of species of Lake Cartma, limnophiles are dominated (waders). The degree of dominance of avifauna species, their share in total quantity of bird species were considered in detail. The lake is characterized by a comparatively small number of birds and low population density of waterfowl. There were five species, listed in the Red Book of the Republic of Kazakhstan. Information is new for the studied object.
\end{abstract}

Keywords: The North Aral Sea, Lake Systems of Syr Darya River Delta, Wetlands, Avifauna, Lake Cartma.

\section{Introduction}

One of the most important environmental problems of our time is the regression of the Aral Sea. Beginning in the 1960's, this phenomenon has not reached its apogee. The level of the reservoir has been fluctuating for about 60 years. However, except for some episodes with temporary stabilization, the overall trend shows a noticeable decline. Within this period, several stages were distinguished, such as, the separation of the Northern Aral Sea from the main reservoir in 1988, the separation of the Large Sea into the eastern and western Aral, and so on [1]. This study was conducted in the water area and the surrounding areas of Lake Cartma, which was separated from the eastern part of the Large Aral Sea, in the early 1990's [2]. Lake Cartma, the flood zone of the Large Aral Sea, is located on the territory of the Aral region of the Republic of Kazakhstan. In the period until 2009, it had been occasionally drained. The current hydrological state is supported by the Syr Darya River through the Karateren Canal, as a result of the construction of the Aklak Dam [2-3]. In the biodiversity of the Northern Aral Sea (NAS) and the system of lakes of the Syr Darya River delta, avifauna is functioned as an indicator of the ecological state of water bodies and the Aral Sea region as a whole [3-4]. The contributing factor is the transit location of water bodies on the main migration route of birds, from wintering grounds of North Africa and South-East Asia to the nesting area in Central and Northern Kazakhstan, Siberia. Due to this, the areas of North Aral Sea and lakes of the Syr Darya River delta are used as a stopping point [5, P. 222]. After all, birds according to B.K. Shtegman (1938), "are extremely conservative in their distribution" [6].

After the putting in operation of the Kokaral dam and the Aklakhydro system, bird counts were carried out in the water area and the surrounding areas of the Northern Aral Sea, the Kamystybas, Akshatau, Aksai, Kuandarya lake systems. The avifauna of the coastal left-bank reservoirs, especially of Lake Cartma, had not been taken into account until 2014 [1, 3 -5, 7-10]. It is important to note the important environmental part of the SYNAS program (Syr Darya Control and Northern Aral Sea).As a result of restoration, the wetlands of the Northern Aral Sea and the system of lakes of the Syr Darya River delta were included in the list of key ornithological sites, protected by the international Ramsar Convention [8]. The fauna and especially the bird population of the Aral Sea and the delta of the Syr Darya River are well studied [1, 3-5, 7-11]. Therefore, the identification of characteristic features of the bird population of the investigated object is very important in ornitho-geographical terms.

\section{Methods}

The investigations were carried out in the water area and surrounding areas of Lake Cartma. The maximum area of the reservoir is $8.0 \mathrm{~km}^{2}$. During the survey period (from June 28 to July 3, 2016), the water level was $51.69 \mathrm{~m}$, according to the Baltic System (BS), the area of the lake was $6.2 \mathrm{~km}^{2}$ [2]. The coastline was about $12 \mathrm{~km}$. The banks were 
shallow, slightly indented. The southeastern and eastern parts of the reservoir were flooded and the approaches to it were occupied by thick reedbed (Phragmitesaustralis), from 2 to $4 \mathrm{~m}$ in height. Due to the inaccessibility of this site for full monitoring, it was decided to route along the Northern, northwestern and southern parts of the reservoir [3-4].

The wetland ecosystems of the reservoir are represented by high reedbed (Phragmitesaustralis) with hydrophytic herbage (Typhaangustifolia, Scirpuslacustris, Scirpustabernemontanii), air-water (Sparganium simplex, Alismaplantago-aquatica) and submerged-aquatic (Potamogetonperfoliatus, Najas marina) macrophytes $[1,3]$.

The material was collected in late June - early July, 2016, when the species composition and the number of nesting birds are relatively stable. The work of A.S. Bogolyubov [12] and Yu.S.Ravkin [13], adjusted for the open area, was a methodological basis for conducting route surveys. 8-fold binoculars and photographic equipment were used in the work. Birds were counted on permanent, but not strictly fixed, linear routes, located along the shore of the reservoir with weekly replication. Route counts, adjusted for open terrain, with the length of $10 \mathrm{~km}$, lying parallel to the shore of the lake, in 20 meters from the water's edge, was divided into 2 sections of five kilometers each: the first section located on the northern part of the lake and passed counterclockwise along the line northeast - north - northwest; the second section continued the previous route and covered the west coast of the lake along the line north-west - west-south-west [12-13].

The scale of abundance score, proposed by A.P. Kuzyakin [14, p. 55-59] was used for the description of birds' distribution. Graduation of dominance degree, proposed by A.P. Kuzyakin [12], provided for three main units, namely: dominants, the percentage ratio of which was from 10 to $100 \%$, corresponding in abundance to very numerous species, their number was 100-999 individuals per 1 $\mathrm{km}^{2}$; secondary - 1-9\% (numerous - 10-99 individuals per $1 \mathrm{~km}^{2}$ ); and third-rate - 0.1-0.9\% (common - 1-9 individuals per $1 \mathrm{~km}^{2}$ ). Due to the presence in the counts of such species, the abundance and percentage ratio of which were beyond the classification, it seemed more reasonable to add the following grades: $0.01-0.09 \%$ (rare - 0.1-0.9 individuals per $1 \mathrm{~km}^{2}$ ), $0.001-0.009 \%$ (very rare - 0.01-0.09 individuals per $1 \mathrm{~km}^{2}$ ). In the process of determining the species, the authors were guided by the determinants and reference books of V.K. Ryabitsev and co-authors [15], "Birds of Kazakhstan" [16-18], as well as foreign sources [19-33]. Types of avifauna were presented according to B.K. Shtegman [6].

\section{Results and Discussion}

The analysis of scientific works, carried out after the restoration of the Northern Aral Sea shows, that the field studies were carried out within the framework of a comprehensive study of the lake systems of the Syr Darya delta in 2005, 2011, 2012, 2013, but there was not the task to count the birds of Lake Cartma[1, 3 -5, $7-11,34]$ and to study the patterns of ornithocenosis formation.

In the scientific literature, up to 2014, there has been no data on the diversity of the avifauna of Lake Cartma, but there was general regional data on the avifauna of lakes in the delta of the Syr Darya River $[5,9-11,34]$.

To date, according to the classification of the avifauna of Northern Eurasia, the territory of our study is located within the boundaries of the following areas: a flat region of the western province of a desert subregion; the Aralo-Balkhash District of the western province of the temperate-island subregion [35].

Species Diversity. The results of surveys the species composition and the number of birds are presented in Table 1. 59 species of birds, belongingto 10 orders were defined: ciconiformes (Ciconiiformes); anseriformes (Anseriformes); birds of prey (Falconiformes); fowl-like birds(Galliformes); gruiformes(Gruiformes); shore birds (Charadriiformes); pigeons (Columbiformes); coraciiformes(Coraciiformes); upupiformes(Upupiformes); perching birds (Passeriformes) [19-25].

Three groups of birds are represented in the avifauna of the lake (see Table 1). The main group, which includes the largest number of species, is the birds of wetlands (egrets, dabbling and diving ducks, coots, waders, gulls, terns, etc.) [32-33]. The second group consists of the representatives of the order perching birds (Passeriformes), the habitat of which, in one way or another, is connected with adjoining grass and shrub complexes and nearby settlements, such as wagtails, warblers, swallows, corvidae species, wheatears, etc. [16-18]. Among the representatives of predatory birds, there are harriers, buzzards, eagles, falcons [26-31]. 
Table 1 Results of Bird Counts of Lake Cartma

\begin{tabular}{|c|c|c|c|}
\hline № & Species & $\begin{array}{l}\text { Numberofindi } \\
\text { viduals }\end{array}$ & Share from TNSS, $\%$ \\
\hline 1. & Egretta albaL. & 3 & $0.1 \%$ \\
\hline 2. & ArdeacinereaL. & 4 & $0.1 \%$ \\
\hline 3. & ArdeapurpureaL. & 16 & $0.5 \%$ \\
\hline 4. & Plegadisfalcinellus L.(RB) & 28 & $0.9 \%$ \\
\hline 5. & Anseranser L. & 2 & $0.1 \%$ \\
\hline 6. & Cygnus olorGmelin & 7 & $0.2 \%$ \\
\hline 7. & Tadorna tadorna $\mathrm{L}$. & 2 & $0.1 \%$ \\
\hline 8. & Anas platyrhynchos $\mathrm{L}$. & 40 & $1.3 \%$ \\
\hline 9. & Anascrecca L. & 17 & $0.5 \%$ \\
\hline 10. & Anasquerquedula $\mathrm{L}$. & 51 & $1.6 \%$ \\
\hline 11. & Nettarufina Pall. & 60 & $1.9 \%$ \\
\hline 12. & AythyanyrocaGuldenstadt(RB) & 8 & $0.3 \%$ \\
\hline 13. & Circus aeruginosus L. & 6 & $0.2 \%$ \\
\hline 14. & Buteo rufinusCretzschmar & 7 & $0.2 \%$ \\
\hline 15 . & Aquila heliacaSavigny(RB) & 1 & $0.03 \%$ \\
\hline 16. & FalconaumanniFleischer & 2 & $0.1 \%$ \\
\hline 17. & Phasianuscolchicus (turcestanicus) Lorenz (RB) & 2 & $0.1 \%$ \\
\hline 18. & GrusgrusL. & 71 & $2.3 \%$ \\
\hline 19. & Fulicaatra $\mathrm{L}$. & 205 & $6.5 \%$ \\
\hline 20. & Burhinusoedicnemus L. & 43 & $1.4 \%$ \\
\hline 21. & CharadriusdubiusScopoli & 4 & $0.1 \%$ \\
\hline 22. & Chettusiagregaria Pall.(RB) & 1 & $0.03 \%$ \\
\hline 23. & Vanellusvanellus L. & 6 & $0.2 \%$ \\
\hline 24. & Vanellochettusia leucuraLichtenstein & 270 & $8.6 \%$ \\
\hline 25. & HimantopushimantopusL. & 200 & $6.4 \%$ \\
\hline 26. & Tringaochropus L. & 7 & $0.2 \%$ \\
\hline 27. & Tringaglareola $\mathrm{L}$. & 2 & $0.1 \%$ \\
\hline 28. & TringanebulariaGunnerus & 2 & $0.1 \%$ \\
\hline 29. & Actitis hypoleucos L. & 3 & $0.1 \%$ \\
\hline 30. & XenuscinereusGuldenstadt & 5 & $0.2 \%$ \\
\hline 31. & CalidrisminutaLeisler & 7 & $0.2 \%$ \\
\hline
\end{tabular}




\begin{tabular}{|c|c|c|c|}
\hline 32. & LimicolafalcinellusPontoppidan & 1 & $0.03 \%$ \\
\hline 33. & LymnocryptesminimusBrunnich & 1 & $0.03 \%$ \\
\hline 34. & Gallinagogallinago L. & 2 & $0.1 \%$ \\
\hline 35. & Glareolapratincola $\mathrm{L}$. & 20 & $0.6 \%$ \\
\hline 36. & Laruscachinnans Pall. & 38 & $1.2 \%$ \\
\hline 37. & Laruscanus L. & 4 & $0.1 \%$ \\
\hline 38. & Chlidoniasniger $\mathrm{L}$. & 96 & $3.1 \%$ \\
\hline 39. & Chlidoniasleucopterus L. & 600 & $19.1 \%$ \\
\hline 40. & Gelochelidon niloticaGmelin & 14 & $0.4 \%$ \\
\hline 41. & Hydroprognecaspia Pall. & 27 & $0.9 \%$ \\
\hline 42. & Sternahirundo L. & 27 & $0.9 \%$ \\
\hline 43. & Sterna albifrons Pall. & 16 & $0.5 \%$ \\
\hline 44. & Columba livianeglecta Hume & 43 & $1.4 \%$ \\
\hline 45. & Meropspersicus Pall. & 13 & $0.4 \%$ \\
\hline 46. & Upupa epops L. & 2 & $0.1 \%$ \\
\hline 47. & Ripariariparia L. & 142 & $4.5 \%$ \\
\hline 48. & Hirundo rustica $\mathrm{L}$. & 544 & $17.3 \%$ \\
\hline 49. & Motacillaflava L. & 112 & $3.6 \%$ \\
\hline 50. & MotacillafeldeggMichahelles & 72 & $2.3 \%$ \\
\hline 51. & MotacillapersonataGould & 246 & $7.8 \%$ \\
\hline 52. & PicapicabactrianaBonaparte & 2 & $0.1 \%$ \\
\hline 53. & Corvusfrugilegus L. & 6 & $0.2 \%$ \\
\hline 54. & CorvuscornixsharpiiOates & 4 & $0.1 \%$ \\
\hline 55. & Corvusruficollis Lesson & 9 & $0.3 \%$ \\
\hline 56. & Acrocephalus scirpaceus Hermann & 2 & $0.1 \%$ \\
\hline 57. & AcrocephalusstentoreusHemprich et Ehrenberg & 2 & $0.1 \%$ \\
\hline 58. & Oenanthe desertiTemminck & 4 & $0.1 \%$ \\
\hline 59. & Emberiza schoeniclus L. & 16 & $0.5 \%$ \\
\hline \multicolumn{2}{|r|}{ Total } & 3147 & 100 \\
\hline
\end{tabular}

Note. RB - is the species, listed in the Red Book of the Republic of Kazakhstan.

59 species, with a total number of 3,147 individuals were defined in the process of counts in 2016. 5 species are listed in the Red Book of the Republic of Kazakhstan (see Table 1).

The structure of the bird population, according to the relative abundance of species. There is 2dominant species (whose share in the general population exceeds $10 \%$ ), and their density is $36.4 \%$ (see Table 1). White-winged Black Tern (Chlidoniasleucopterus L.)is the dominant species with a share of $19.1 \%$.European swallow 
(Hirundorustica L.)is a codominant species (17.3\%) [15-16].

The share of secondary species (degree of dominance within the range of $1-9 \%$ ) is 15 , with a density of $53.7 \%$. Among the secondary species, white-tailed lapwing dominates $(8.6 \%)$ [17-18].

The third-rate species $(0.1-0.9 \%)$ are the basis of the ornithocenosis, in terms of the number of species. There were 43 species, with a density of $9.9 \%$ [1921].

It should be noted the species, listed in the Red Book of Kazakhstan and defined during the surveys. There were glossy ibis (Plegadisfalcinellus), Ferruginous Duck (Aythyanyroca), imperial eagle (Aquila heliaca), Phasianuscolchicus (turcestanicus), sociable plover (Chettusiagregaria)[15, 22-24].

To a greater extent, differences in bird communities are manifested when analyzing the structure of the lake's ornithofauna by origin, according to the concept of fauna types of B.K.Shtegman [6]. There are as transpalearctic species, as the species of Arctic, Siberian, European, Mediterranean, Mongolian, Chinese, Holarctic origins, i.e. mixed ornithogeographical type.

\section{Summary}

1. The counts of the birds of Lake Cartma were initiated with the purpose of scientific justification of the dynamics of avifauna population in certain phases of the period of water bodies' restoration.

2. Observations of the avifauna of the studied area in the summer (nesting) period have been conducting for the third year in a row.

3. As a result of scientific expedition, a comparatively rich species and quantitative diversity of avifauna was defined.

4. Studied species of birds are the representatives of a mixed ornitho-geographical type.

\section{Conclusion}

Thus, as a result of the research, preliminary data on the diversity of the ornithocene of Lake Cartma were obtained. A total of 59 species of birds from 10 orders were defined. The development of aquatic vegetation, favorable conditions of the hydrological regime: depth, transparency and water temperature contribute to the active colonization of the studied area. It should be noted the facts of dense reed weediness and the presence of dense thickets of typha, which provides protection for most birds from humans, dogs and predators. The relative poverty of the fauna is explained by the fact, that the lake systems of the Syr Darya River delta and the Aral Sea are currently under restoration and natural succession. Probably, the intensive siltation of reservoirs and the absence of direct communication between the lake and the Large Aral Sea play its role. However, Lake Cartma, like other reservoirs of the
Syr Darya delta lake system, is gradually being restored, and takes a significant part in maintaining the biodiversity of the Aral Sea region, and also serves as a place of birds' consolidation during the migration period.

\section{Acknowledgement}

The work is performed according to the Russian Government Program of Competitive Growth of Kazan Federal University.

\section{References}

[1] Sihanova N.S., Rahimov I.I. Inhabitants and ecology of Lake Cartma birds // Bulletin of the Peoples' Friendship University, series Ecology and Life Safety, 2016, №4. - Pp. 33-43.

[2] Askarov A.G. Report on the hydrological state of the Syr Darya River, delta lake systems and the Aral Sea, August 2016 // Institute of Geography.Priaral environmental center.Kent Aiteke bi, 2015. Pp. 4-21.

[3] Sihanova N.S., Rahimov I.I. Avifauna of lake systems in Syr Darya river Delta (Cartma lake) // International Journal of Pharmacy \& Technology. Issue \#2, Vol. 8. 2016. - Pp. 14624-14633. ISSN: 0975-766X.

[4] Sihanova N.S., Rahimov I.I. Peculiarities of the ornitocene and phytocenosis of Lake Cartma in the Northern Aral restoration zone (results of the 2014 expedition) // Modern Science: Actual Problems of Theory and Practice. Series "Natural and Technical Sciences". 2016. №1. - Pp. 3-8.

[5] Dimeeva L.A. et al. Conservation of wetlands biodiversity in avandeltaof the Syr Darya River // Bulletin of KazNU. Ecological series. №1 (33). 2012. - Pp. 220-222.

[6] Shtegman B.K. Fundamentals of the ornithogeographic division of the Palearctic// Fauna of the USSR. Birds.M.; L., 1938.Vol. 1, ed. 2. 156p.

[7] Sihanova N.S. Avifauna of lake Cartma // "Science in the modern information society" Materials of the VI Int. scientific-practical. Conf. North Charleston, USA.Vol. 2. 2015. - Pp. 19-20.

[8] Guide to the Ramsar Convention on Wetlands of Central Asia / Ed. by L. Young, E. Andersley, S.L. Sklyarenko, A. Solokha, E. Kreuzberg-Mukhina and M. Brombaher. - Berlin, 2012. - 112 p.

[9] Berezovikov N.N. Materials to the avifauna of the avandelta of the Syr Darya and the Small Aral Sea // Russian ornithological journal. 2012. Vol. 21, Express edition 775. Pp. 1619-1653.

[10] Berezovikov N.N. Materials to the avifauna of the Small Aral Sea, the avandelta of the Syr Darya, Akshatau and Kamystybas lake systems // Russian ornithological journal. 2014. Vol. 23, Express Edition 986. Pp. 1065-1087.

[11] Berezovsky V.G. Comparative characteristics of migrations of waterfowl and waterbirds on the eastern coast of the Aral Sea and in the lower reaches 
of the river Turgai. Diss. for the degree level of Cand.Biol. Sciences, Alma-Ata, 1984.188 p.

[12] Bogolyubov A.S. The study of the species composition and number of birds by the method of route registration // Ecosystem. 1999. 8 p.

[13] RavkinYu.S. To the methodology of counting birds in forest landscapes // Nature of foci of tickborne encephalitis in the Altai. Novosibirsk: Nauka, 1967. Pp. 66-75.

[14] Kuzyakin A.P. Zoogeography of the USSR // Transactions of Moscow Regional Pedagogical Institute n.a. N.K. Krupskaya. 1962. Vol. 109, №1. Pp. 55-59.

[15] Field determinant of birds of Kazakhstan / V.K. Ryabitsev, A.F. Kovshar, V.A. Kovshar, N.N. Berezovikov; Almaty, 2014. 512 p.

[16] Dolgushin I.A. Birds of Kazakhstan. Vol. 1. Alma-Ata, Publishing house of the Academy of Sciences of the Kazakh SSR, 1960.469 p.

[17] Birds of Kazakhstan. Volume 2. V.F. Gavrin, I.A. Dolgushin, M.N. Korelov, M.A. Kuzmina; Under the general editorship of IA. Dolgushin. AlmaAta: Publishing house of the Academy of Sciences of the Kazakh SSR, 1960. 783 p.

[18] Birds of Kazakhstan. Volume 3. I.A. Dolgushin, M.N. Korelov, M.A. Kuzmina et al.; Under the general editorship of IA. Dolgushin, M.N. Korelov. Alma-Ata: Publishing house of the Academy of Sciences of the Kazakh SSR, 1970. 328 p.

[19] Aye R. Schwiezer M., Roth T. Birds of Central Asia (Kazakhstan, Turkmenistan, Uzbekistan, Kyrgyzstan, Tajikistan and Afghanistan) - Field Guide. London, 2012.336 p.

[20] Gavrilov E., Gavrilov A. The Birds of Kazakhstan // Tethys Ornitological Research, vol. 2. Almaty, 2005, - Pp. 1-228.

[21] Message S., Taylor D. Field Guide to the Waders of Europe, Asia \& North America. Christopher Helm London. 2005. 224 p.

[22] D.D. Harber. The birds of the Soviet Union// Vol.48. №06. - Pp. 268-276.

[23] Klaus Malling Olsen, Hans Larsson. Gulls of North America, Europe, and Asia.Princeton University Press.Princeton and Oxford. 2004. 608 p.

[24] Lars Svensson. Identification guide to European Passerines. Fourth, revised and enlarged edition. Stockholm. 1992. 368 p.

[25] Viktor P.Belik. The sociable lapwing in Eurasia: what does the future hold?// British Birds 98. September 2005. - Pp. 476-485.

[26] Rasmussen Pamela C. \& John C. Anderton. Birds of South Asia. The Ripley Guide. V. 1-2. Smithsonian Institution and Lynx Edicions. 2005 (second edition 2012). Vol. 1: 384 pp., Vol. 2: 688 p. [27] Wassink, A.\& G.J.Oreel. 2008. Birds of Kazakhstan: new and interesting data. Dutch Birding 30. 2008. Pp. 93-100.

[28] David T.Parkin, Martin Collinson, Andreas J. Helbig, Alan G. Knox and George Sangster. The taxonomic status of Carrion and Hooded Crows// British Birds 96. June 2003. - Pp. 274-290.

[29] Svensson L. Collins Bird Guide. 2-nd edit. Harper Collins Publishers Ltd. London. 2010. 446 p. [30] Svensson L., Grant P.J., Mullarney K., Zetterstrom D. Collins Bird Guide. The most complete Field Guide to the Birds of Britain and Europe. London, 1999/392 p.

[31] Kenneth Williamson. Birds and climatic change// Bird Study. 1975. - Pp. 143-164. 2009. DOI: $10.1080 / 00063657509476459$.

[32] Kovalenko A.V. Ornithological studies in the valley of the lower Syr Darya and some adjacent territories in 2005 // Kaz. Ornithol.bulletin. 2005. Pp. 59-69.

[33] Blinova T.K., RavkinYu.S. Ornitho-faunistic zoning of Northern Eurasia // Siberian Ecological Journal, 1 (2008), - Pp. 101-121. 